\title{
The impact of smog on the design of sports facilities $^{1}$
}

\author{
Wojciech Zabłocki
}

\begin{abstract}
The smog phenomenon and its health consequences seem to be nowadays a real problem for many societies, including Poland. In addition, the question arises as to what impact it may have on urban planning and architectural design. Scientists believe that there are only three methods to avoid the dangerous smog pollution: trying to stay indoors during smog alerts, avoiding outdoor exercise and using special masks. However, using masks during exercising is unhealthy due to the reduction of the body's oxygenation. Special attention should be paid to the location of open sports areas for young citizens. Air-conditioned sports halls would be the best option for those who want to be physically active during smog alerts.
\end{abstract}

Key words: smog, stadiums and playing fields, sports halls

The smog phenomenon and its health consequences are currently in the centre of attention of many societies, including Polish. In addition to counteracting the formation of smog, the question arises as to what impact it can have on urban planning and architectural design. In this article, I try to answer the question what might be the relation between smog formation, especially in cities, and the planning and design of sports facilities.

The doctors' opinion is clear: in principle, there are only three effective methods of protection a person from harmful airborne dust. These are: trying to stay indoors during high smog levels, avoiding physical exertion, especially outdoors, and using dust masks. However, the use of masks during physical exertion is not healthy because it limits the body's oxygenation.

The average smog concentration varies in different locations and can be monitored by a network of sensors. These results can be taken into account in the future when issuing locations and constitute one part of the plans.

Smog is largely generated by vehicular transport, therefore locating sports facilities, especially outdoor facilities, close to busy streets and intersections creates a risk for users. The idea of locating recreational facilities, such as tennis courts or swimming pools on the

\footnotetext{
${ }^{1}$ With great pleasure, and at the same time with great sadness, we present to you a short article written by Professor Wojciech Zabłocki. With pleasure, because the text deals with a very important, current and global problem, and shows that even in the last years of his life, Professor Zabłocki focused on important matters of everyday life, was able to link them with his beloved sport and presented a scientific model of seeing and explaining the reality around us.

We are saddened by the fact that this is the last text written by the Professor for our editorial office, a symbolic "final touch" of his sports, professional, scientific and artistic achievements.
} 
roofs of commercial or hotel buildings, in dense urban development is considered misguided (Fig. 1).

It is important to understand that most open stadiums, also in Warsaw, are located in the city centres and are surrounded by busy thoroughfares and parking lots. Dates of games at the stadiums cannot depend on smog alerts. Both players and spectators may be exposed during matches to harmful effects of airborne dust. Spectators can wear masks, and players should receive appropriate post-exercise treatment to reduce the harmful effects of smog. The location of new stadiums should follow the anti-smog monitoring guidelines. An additional design factor will be the natural

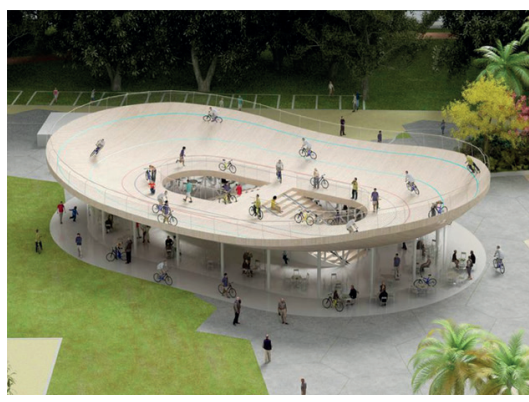

Fig. 1. A velodrome on the roof of a café in Hainan Province in China Designed by NL architects from Amsterdam

Source: TVN24.pl press information ventilation of the stadium's arena and stands.

Special consideration should be given to the location of outdoor training stadiums for youth, who are more sensitive to smog than trained players. The field facilities for youth should be located in open, green and well-ventilated areas. Locating training fields for youth near the Legia stadium in Warsaw, at the junction of busy thoroughfares, is a negative example.

School playgrounds face certain problem, as schools are also located in areas frequently affected by smog. During alerts, students can exercise in school sports halls. Playgrounds like Orlik should also have sports halls at their disposal. The best solution for providing sports and recreation in all conditions are, of course, indoor facilities, if possible air-conditioned. Their number is limited due to high construction and operating costs.

When there are no smog alerts, nothing stands in the way of practicing sports and outdoor recreation. Examples include bicycle races and street running events.

\section{Wpływ smogu na projektowanie obiektów sportowych}

\section{STRESZCZENIE}

Zjawisko smogu i związane $\mathrm{z}$ nim konsekwencje zdrowotne stanowią $\mathrm{w}$ dzisiejszych czasach poważny problem i wyzwanie dla społeczeństw wszystkich zamieszkanych kontynentów, w tym Polski.

Ponadto pojawia się pytanie, jaki może to mieć wpływ na urbanistykę, planowanie i projektowanie architektoniczne. Naukowcy uważaja, że istnieja tylko trzy metody na uniknięcie niebezpiecznego zanieczyszczenia smogiem: próba pozostania w domu podczas alarmów smogowych, unikanie ćwiczeń na świeżym powietrzu i używanie specjalnej maski. Jednak używanie masek podczas ćwiczeń jest niezdrowe ze względu na zmniejszone natlenienie organizmu. Szczególną uwagę należy zwrócić na lokalizację otwartych terenów sportowych przeznaczonych dla młodzieży. Klimatyzowane hale sportowe to najlepsze rozwiązanie dla tych, którzy chcą być aktywni fizycznie w dniach, kiedy ogłaszane są alarmy smogowe.

Słowa kluczowe: smog, stadiony i boiska, sale sportowe 